\title{
EVALUATION OF THE EFFECTIVENESS OF TRANSFORAMINAL EPIDURAL STEROID INJECTION IN FAR LATERAL LUMBAR DISC HERNIATIONS
}

\author{
Sevket EVRAN', Salim KATAR ${ }^{2}$ \\ 'Department of Neurosurgery, Haseki Research and Training Hospital, Istanbul, Turkey \\ ${ }^{2}$ Department Neurosurgery, Balıkesir University, Balıkesir, Turkey
}

English | https://doi.org/10.18071/isz.74.0027 | www.elitmed.hu

\begin{abstract}
Background and purpose - Far lateral lumbar disc herniations (FLDH) consist approximately $0.7-12 \%$ of all lumbar disc herniations. Compared to the more common central and paramedian lumbar disc herniations, they cause more severe and persistent radicular pain due to direct compression of the nerve root and dorsal root ganglion. In patients who do not respond to conservative treatments such as medical treatment and physical therapy, and have not developed neurological deficits, it is difficult to decide on surgical treatment because of the nerve root damage and spinal instability risk due to disruption of facet joint integrity. In this study, we aimed to evaluate the effect of transforaminal epidural steroid injection (TFESI) on the improvement of both pain control and functional capacity in patients with FLDH.
\end{abstract}

Methods - A total of 37 patients who had radicular pain caused by far lateral disc herniation which is visible in their lumbar magnetic resonance imaging (MRI) scan, had no neurological deficit and did not respond to conservative treatment, were included the study. TFESI was applied to patients by preganglionic approach. Pre-treatment Visual Analogue Scale (VAS) and Oswestry Disability Index (ODI) scores of the patients were compared with the 3rd week, 3rd month and 6th month scores after the procedure.

Results - The mean initial VAS score was $8.63 \pm 0.55$, while it was $3.84 \pm 1.66,5.09 \pm 0.85,4.56 \pm 1.66$ at the 3rd week, 3rd month and 6th month controls, respectively. This decrease in the VAS score was found statistically significant $(p=0.001)$. ODI score with baseline mean value of $52.38 \pm 6.84$ was found to be $18.56 \pm 4.95$ at the $3 \mathrm{rd}$ week, $37.41 \pm 14.1$ at the $3 \mathrm{rd}$ month and

\author{
A TRANSFORAMINALIS EPIDURALIS \\ SZTEROIDBEFECSKENDEZÉS HATÉKONYSÁGÁNAK \\ ÉRTÉKELÉSE TÁVOLI LATERALIS ÁGYÉKI SÉRV ESETÉN \\ Evran S, MD; Katar S, MD \\ Ideggyogy Sz 2021;74(1-2):27-32.
}

Háttér és cél - Az összes ágyéksérv körülbelül 0,7-12\%-a távoli lateralis ágyéksérv (FLDH). Az FLDH a gyakoribb centrális és paramedialis ágyéksérvekhez képest súlyosabb és tartósabb radicularis fájdalmat okoz az ideggyök és a dorsalis gyöki ganglion közvetlen összenyomódása miatt. Azoknál a betegeknél, akik nem reagálnak a konzervatív kezelésre, így például a gyógyszeres kezelésre vagy a fizikoterápiára, és akiknél még nem alakultak ki neurológiai hiánytünetek, az ideggyök sérülése és a synovialis ízületek károsodása miatti gerincinstabilitás kockázata miatt nehéz dönteni a mútét szükségességéről.

Vizsgálatunkban a transforaminalis epiduralis szteroidinjekció (TFESI) hatását kívántuk értékelni mind a fájdalomkontroll, mind a funkcionális kapacitás javulására FLDH-ban szenvedő betegeknél.

Módszerek - Összesen 37 olyan, konzervatív kezelésre nem reagáló, neurológiai hiánytünetmentes beteget vontunk be a vizsgálatba, akinek radicularis fájdalmát az ágyéki MR-felvételen látható távoli lateralis ágyéksérv okozta. A betegeknél praeganglionos irányból TFESI alkalmazására került sor. A betegek kezelés elótt felvett vizuális analóg skála (VAS) és Oswestry Disability Index (ODI) pontszámait a beavatkozás utáni 3. hét, továbbá 3. és 6 . hónap VAS- és ODI-pontszámaival hasonlítottuk össze. Eredmények - Az átlagos kezdeti VAS-pontszám 8,63 \pm 0,55 volt, míg a 3 . hét és a 3., 6. hónap VAS-pontszámainak átlagos értéke 3,84 $\pm 1,66 ; 5,09 \pm 0,85 ; 4,56$ $\pm 1,66$ volt. A VAS-pontszám csökkenése statisztikailag szignifikánsnak bizonyult ( $\mathrm{p}=0,001)$. Az átlagos kezdeti ODI-pontszám 52,38 \pm 6,84 volt, míg a 3. hét és a $3 ., 6$. hónap ODI-pontszámainak átlagos értéke 18,56 \pm 4,95; $37,41 \pm 14,1 ; 34,88 \pm 14,33$ volt. Az ODI-pontszám

Correspondent: Dr. Salim KATAR, Department Neurosurgery, Balıkesir University, Balıkesir, Turkey. Telephone: +905346742323, fax: +90 (212) 45962 30. E-mail: salimkatar@gmail.com https://www.orcid.org/0000-0002-8311-1122

Érkezett: 2020. augusztus 17. Elfogadva: 2020. december 21. 
$34.88 \pm 14.33$ at the 6 th month. This downtrend of patient's ODI scores was found statistically significant $(p=0.001)$. Conclusion - This study has demonstrated that TFESI is an effective method for gaining increased functional capacity and pain control in the treatment of patients who are not suitable for surgical treatment with radicular complaints due to far lateral lumbar disc hernia.

Keywords: far lateral lumbar disc herniation, transforaminal epidural steroid injection, VAS, ODI

$F_{v}^{a}$ ar lateral lumbar disc herniation (FLDH), in which the herniated fragment migrates to the underneath and lateral side of the facet joint, is also known as foraminal, intraforaminal or extreme lateral disc herniation in the literature ${ }^{1}$. FLDH is detected in $0.7-12 \%$ of all lumbar disc herniations $^{1-4}$ in which the nerve root compression occurs at the same level of herniated disc, rather than at inferior root as in median and paramedian disc herniations (Figure 1). Because of FLDH locates at the outside of spinal canal, it can be hidden and unrecognisable by routine conventional imagings. In FLDH, more severe and persistent radicular pain occurs due to direct compression to the dorsal root ganglion compared to the median or paramedian disc herniations ${ }^{5}$. Additionally to conservative treatment methods such as medical treatment and physical therapy, minimally invasive treatment methods like epidural steroid injection (ESI) are the options for the non-surgical treatment of FLDH. ${ }^{2}$ In patients who do not respond to conservative treatment with no neurological deficits, it is challenging to decide on surgical treatment due to the risk of nerve root injury and spinal instability

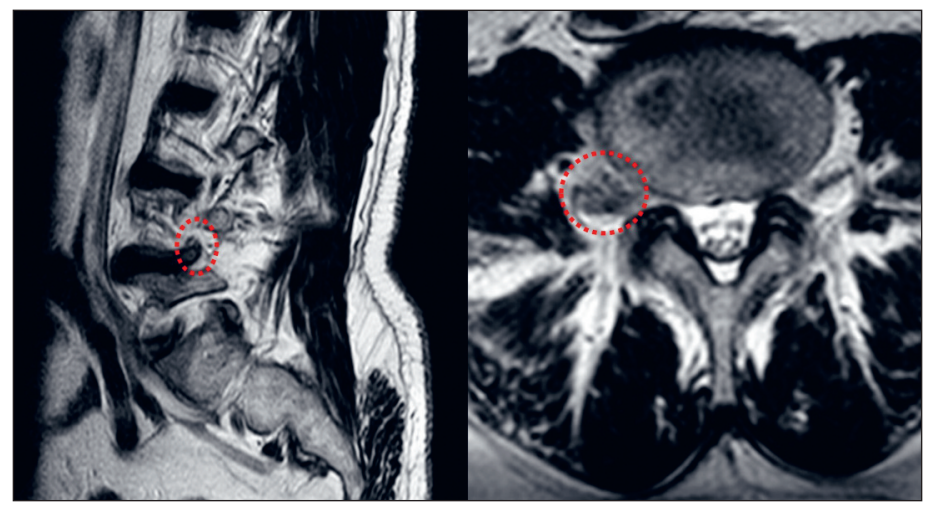

Figure 1. Sagittal and axial MRI sections of a right L4-5 far lateral lumbar disc herniation patient who is included to the study csökkenése statisztikailag szignifikánsnak bizonyult $(p=0,001)$.

Következtetés - Ez a tanulmány kimutatta, hogy a TFESI hatékonyan javítja a funkcionális kapacitást és a fájidalomkontrollt olyan betegek esetén, akik távoli lateralis ágyéksérv miatti radicularis tüneteit nem lehet mútéti úton kezelni.

Kulcsszavak: távoli lateralis ágyéksérv, transforaminalis epiduralis szteroidbefecskendezés, VAS, ODI

caused by and impaired facet joint integrity ${ }^{6}$. Stabilisation and spinal fusion surgeries performed for spinal instability may cause morbidities that can decrease both surgeon and patient satisfaction ${ }^{7}$. Reducing the incidence of these morbidities can be possible by considering non-surgical treatment options. Therefore, in this study, we aimed to evaluate the effect of transforaminal epidural steroid injection (TFESI), which is a minimally invasive treatment method, on the improvement of both pain control and functional capacity in patients with FLDH, who do not respond to conservative treatment methods and have no neurological deficits.

\section{Materials and methods}

\section{STUDY DESIGN}

Medical records of 37 patients who were referred to our clinic between January 2017 and July 2019 and underwent TFESI procedure due to radicular pain caused by FLDH were reviewed retrospectively. The mean age was $51.9 \pm 11.63$ and the range of age was from 32 to 77 . All participants were informed in detail and signed consent forms before the procedure.

\section{PATIENT INCLUSION-EXCLUSION CRITERIA}

Patients had radicular leg pain and no relief despite the conservative treatments for more than a month, with a single level FLDH, which was detected on the lumbar MRI scans and correlated with the patient's complaints were included the study. Patients with additional lumbar pathology such as median / paramedian disc herniation, spinal stenosis, lateral recess stenosis or spondylolisthesis were excluded. Additionally, patients with infection / sepsis, pregnancy, 
anticoagulant / antiaggregant drug use, local anesthetic / steroid allergy, and previous history of lumbar surgery or lumbar epidural injection were not included in the study. Patients who underwent surgical treatment due to the development of neurological deficits were excluded from the study.

\section{TFESI PROCEDURE}

Vital parameters such as blood pressure, pulse, electrocardiography and oxygen saturation were monitored and followed by ensuring vascular access. After the patients were positioned pronely, the surgical area was cleaned with an iodine-based antiseptic solution and was covered with sterile drapes to obtain surgical sterilization. In the next stage, C-arm fluoroscopy (GE Brivo OEC 785, Beijing, China) was used for determining the level. After anterior-posterior (AP) shots, C-arm fluoroscopy positioned obliquely with an angle of 15$20^{\circ}$ for localizing the foramen. In this stage there were no double contours in the end-plates of the vertebrae. The procedure started with the application of local anesthesia before the intervention. After local anesthesia was applied with injection of $1 \mathrm{mg} 1 \%$ lidocaine under the skin, TFESI was performed with a preganglionic approach as described by Lee et al.8, 9 . Skin and subcutaneous tissues passed with a 22-gauge $90 \mathrm{~mm}$ lumbar puncture needle (Egemen International, Izmir, Turkey), and the tip of needle was directed to the intervertebral foramen. Serial lateral and oblique $\mathrm{x}$-rays were done by fluoroscopy to confirm the foramen was entered and to prevent possible neural injuries. After the confirmation of the foramen was reached via lateral and AP X-rays, $0.5 \mathrm{cc}$ radio-opaque solution (Omnipaque 300; iohexol, $300 \mathrm{mg}$ iodine / ml, Amsterdam Health, Princeton, NJ, USA) was injected and the typical ventral epidural spread of the contrast agent was procured (Figure 2). If the image of the anterior epidural spread of the contrast agent could not be obtained, the current appearance was accepted in favor of intravascular injection, and the needle tip was repositioned and the X-rays were done again. If the image of the appropriate contrast distribution could not be obtained for the second time, the process was terminated. After obtaining adequate contrast dispersion, a mixture of $40 \mathrm{mg}$ (1 mL) methylprednisolone acetate (Depo-Medrol, Pfizer Pharmaceuticals Ltd, Lüleburgaz, Kirklareli, Turkey) and $10 \mathrm{mg}(2 \mathrm{~mL})$ of bupivacaine hydrochloride (Marcain 0.5\%, Astra Zeneca, Istanbul, Turkey) were injected in the foramen. Transforaminal epidural injection was performed slowly within

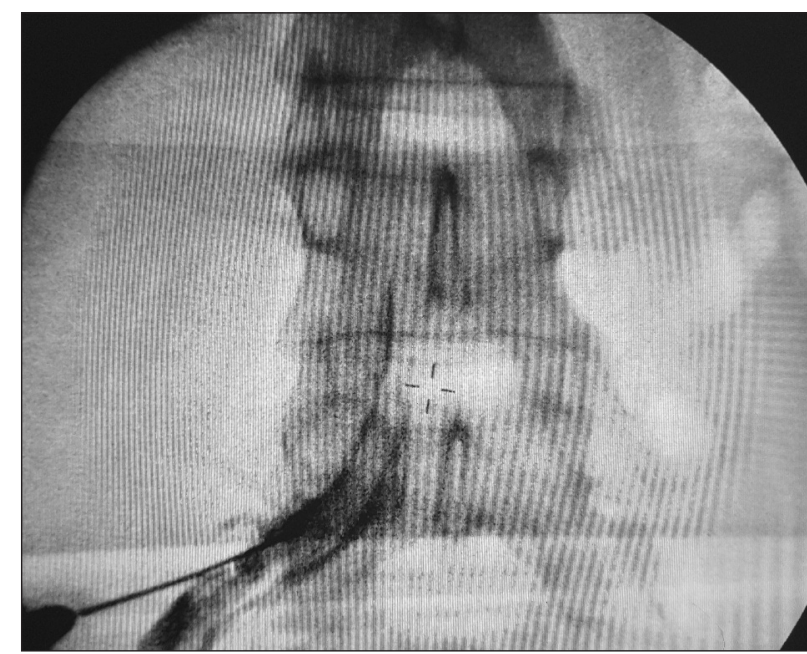

Figure 2. X-ray image of transforaminal epidural steroid injection procedure, which demonstrates the nerve root trace

1-2 minutes. After the procedure, patients were followed up for 4-6 hours in the recovery room for possible early complications and then discharged to be called for controls.

\section{ASSESSMENT PROTOCOL}

Changes in pain levels of patients were evaluated with the Visual Analogue Scale (VAS). With this scale, the patients were asked to rate their pain intensity by giving a score between 0 and 10 . While scoring, it was stated that 0 points represent painlessness and 10 points represent the most severe pain of all time. Changes related to the restriction of daily activities of patients were evaluated with the Oswestry Disability Index (ODI). The ODI is a questionnaire which evaluates the patient's affection from pain with 10 items about intensity of pain, personal care, lifting, walking ability, sitting ability, standing ability, sleep quality, social life, traveling ability, changing degree of pain. Each question has 6 choices and the answers are scaled in a range between 0 to 5 . While 0 points indicate the least amount of disability, 5 points indicate the most severe disability ${ }^{10}$. Values are summed and multiplied by two to evaluate over 100 points. In this scale 0 represents no disability and 100 represents the maximum possible disability.

VAS and ODI measurements were performed before injection (VAS-pre, ODI-pre), 3 weeks after injection (VAS-3w, ODI-3w), 3 months after injection (VAS-3m, ODI-3m) and 6 months after injection (VAS -6m, ODI-6m). The changes in VAS and ODI and the effectiveness of TFESI in FLDH were analyzed. 
Table 1. Demographics and clinical data of study population ( $n=32)$

\begin{tabular}{|cl|}
\hline Age (year) & $45.9(\mathrm{SD} 11.63)$ \\
Gender & range 22-64 \\
male & $\mathrm{n}, \%)$ \\
female & $18(46.25 \%)$ \\
Level & $14(43.75 \%)$ \\
L2-L3 & \\
L3-L4 & $3(9.3 \%)$ \\
L4-L5 & $10(31.2 \%)$ \\
L5-S1 & $14(43.7 \%)$ \\
\hline
\end{tabular}

\section{STATISTICAL ANALYSES}

While performing statistical analysis, descriptive statistical data were used for continuous variables such as mean, standard deviation, minimum, maximum and median. Comparison of changes in pain level before and after injection was done with a paired t-test. A probability (p) value of less than 0.05 was considered statistically significant. Statistical analyzes were performed using SPSS Statistics version 22 (IBM corp. 2013).

\section{Results}

A total of 37 patients were included in our study in a period of 30 months. Five patients who underwent surgical treatment due to the development of neurological deficits during their follow-ups were excluded from the study. There was no statistically significant difference between the demographic data and the initial VAS \& ODI scores of the patients who needed surgery and the study group. Of the 32 patients, $14(43.75 \%)$ were male and 18 $(56.25 \%)$ were female, and the mean age was 51.9

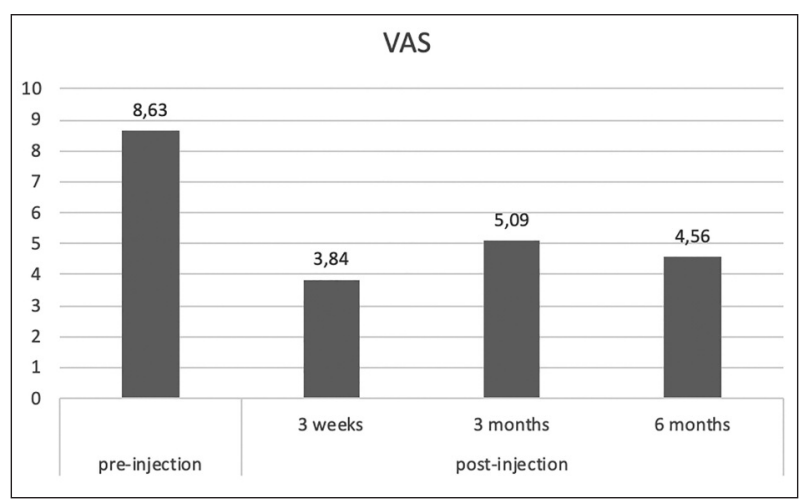

Figure 3. Changes in VAS score of TFESI in pre-and post-injection periods \pm 11.63 . The most common involvement in patients was at L4-L5 (14/32), followed by L3-L4 (10/32), L5-S1 (5/32), and L2-L3 (3/32) levels, respectively (Table 1). VAS and ODI scores at the time of admission, and control VAS and ODI for 3 weeks, 3 months and 6 months after TFSI were evaluated. The mean initial VAS score was $8.63 \pm 0.55$, while it was $3.84 \pm 1.66,5.09 \pm 0.85,4.56 \pm 1.66$ in the 3-week, 3-month and 6-month controls, respectively (Figure 3). This decrease in VAS score was found statistically significant $(p=0.001)$. ODI score with baseline mean value of $52.38 \pm 6.84$ was found to be $18.56 \pm 4.95$ in the 3 rd week, $37.41 \pm$ 14.1 in the 3rd month and $34.88 \pm 14.33$ in the 6th month (Figure 4). During this period, the decrease in ODI scores of patients was found statistically significant $(\mathrm{p}=0.001)$ (Table 2).

\section{Discussion}

FLDH patients have more severely pain than other disc herniations due to dorsal root ganglion compression $^{4,5,11}$; also the symptoms and findings of the patients are usually compatible with the compressed nerve root. FLDH has some clinical differences compared to other lumbar disc herniations. Its clinical findings, prevalence and pathophysiology were first described by Abdullah et al. ${ }^{12}$. These differences are lower positivity of straight leg stretching test, higher positivity of femoral stretching test ${ }^{13}$, radicular pain similar to piercing or stabbing pain, and relatively lower back pain ${ }^{14,} 15$. FLDH differs from other disc herniations not only clinically but also in terms of surgical approach. Surgical techniques previously defined in the literature for FLDH are intertransverse technique, medial facetectomy, extraforaminal approach and total facetectomy ${ }^{3,16}$. While the medial facet and

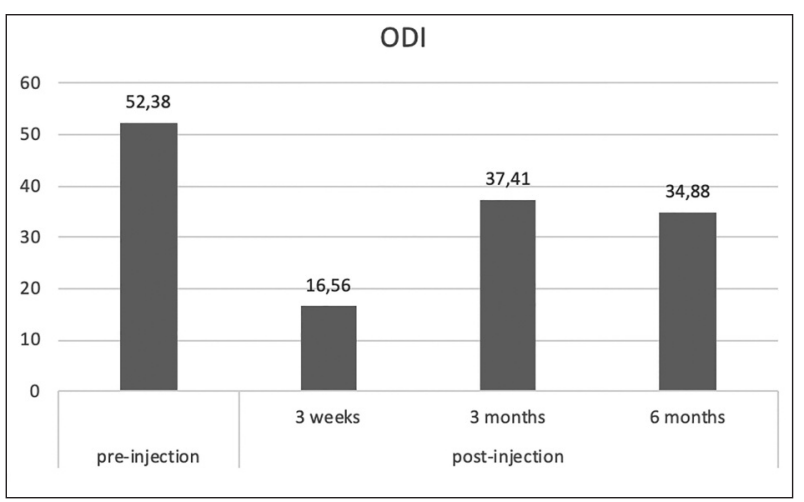

Figure 4. Changes in ODI score of TFESI in pre- and post-injection periods 
Table 2. Comparison of the results of TFESI between pre-post injection

\begin{tabular}{|llllll|}
\hline & Pre-injection & & Post-injection & $\mathrm{p}$ \\
\hline & & 3 weeks & 3 months & 6 months & \\
\hline VAS & $8.63(0.55)$ & $3.84(1.66)$ & $5.09(0.85)$ & $4.56(1.66)$ & 0.001 \\
ODI & $52.38(6.84)$ & $16.56(4.95)$ & $37.41(14.1)$ & $34.88(14.33)$ & 0.001 \\
\hline
\end{tabular}

VAS: Visual Analog Scale, ODI: Ostwestry Disability Index

pars interarticularis are preserved in the intertransverse technique, this technique has higher risk of nerve root injury in case of severe foraminal or far lateral stenosis. In the extraforaminal approach in which the superolateral part of the facet joint is resected, access to the foraminal and intra-canalicular pathologies is limited. In the medial facetectomy technique, which is sufficient to access foraminal lesions, especially at the L5-S1 level, nerve root injury can also be seen during foraminal dissection. In total facetectomy, where the nerve root can be demonstrated safely, stabilization may also be required. ${ }^{3}$ In addition, paraspinal muscle dissection in posterolateral approaches may cause severe pain after surgery ${ }^{16}$. Kabil et al. ${ }^{17}$ suggested the FLDH can not be treated with standard posterior hemilaminectomy and it usually requires extensive bone resection up to total facetectomy, which increases the postoperative instability and thus the recurrence rate. For this reason, endoscopic surgery provides important advantages to prevent complications such as instability, but endoscopic surgery also has disadvantages such as limited field and two dimensional vision ${ }^{18}$. At this perspective FLDH does not have an excellent surgical technique in every respect. Therefore, in patients without definitive surgical indications such as progressive neurodeficit, non-surgical treatments should not be ignored in order to reduce the incidence of complications such as paraspinal pain, nerve damage, instability caused recurrence and reoperation. One of the non-surgical treatments is epidural steroid injection, which is a minimally invasive treatment method. Epidural steroid injections can be applied in three different ways, caudal, interlaminar and transforaminal (TFESI) ${ }^{19}$. TFESI is the most preferred of these 3 methods due to its advantages such as direct medication to the affected nerve root and low volume drug usage necessity ${ }^{20}$. Although $\mathrm{Ab}-$ dullah et al. ${ }^{12}$ reported that the success rate of nonsurgical treatments in FLDH is low, there are contrary opinions in the literature. Rust and Olivero reported the rate of response to non-surgical treatments in FLDH as $71 \%{ }^{21}$.
There are a limited number of studies in the literature that analyze the effectiveness of epidural steroid injection in FLDH. Erhard et al. reported a case that TFESI helped to stop the inflammatory processes that cause pain in FLDH. ${ }^{2}$ In the retrospective study of Kim et al., TFESI was applied to only 5 of 15 patients with FLDH, and 9 patients underwent caudal block and interlaminar epidural injection due to severe radicular pain ${ }^{22}$. In this study, although the number of cases was extremely limited, improvements in VAS and ODI values were found to be statistically significant in patients underwent TFESI. In the study of Gruenberg et al., the effectiveness of periradicular injection was analyzed in 46 patients with foraminal or extraforaminal disc herniation, and it was stated that this method was effective in pain control ${ }^{23}$. However, the efficacy of epidural injection in FLDH has not been fully demonstrated since only 46 patients were evaluated for pain and no assessment was made in favor of functional capacity ${ }^{23}$. In the study of Weiner and Fraser, TFESI was applied to patients with foraminal or extraforaminal disc herniation, and while no statistical analysis was performed, an evaluation was made with an increase in the Low Back Outcome Score ${ }^{24}$. In this study, it was not possible to analyze the effectiveness of epidural injection in FLDH because the number of cases with FLDH was unknown and statistical evaluation was not performed. There are no other studies in the literature evaluating the effectiveness of epidural steroid injection in FLDH.

In our study, TFESI was applied to 32 of 37 included patients. Since all disc herniations were located exterior of the spinal canal in all patients, the effect of TFESI on isolated FLDH was analyzed in our study. In our study, the VAS and ODI scores before intervention, early and late period after the TFESI were measured; and the changes in the scores were statistically analyzed by paired t-test. The fact that the changes in VAS and ODI scores were statistically significant $(\mathrm{p}<0.05)$ has shown that TFESI is an effective method of improving quality of life in FLDH due to improving pain control and increasing functional capacity. 
There are two major limitations in our study. The first limitation of our study is that there was no control group. The presence of a control group would have helped better interpretation of the results. The second limitation of our study is that it was planned retrospectively. However, with the data obtained in this study, we believe that the effect of TFESI on both pain control and improvement in functional capacity of isolated FLDH patients is shown for the first time in the literature.

\section{Conclusion}

This study has demonstrated that TFESI is an effective method for gaining increased functional capacity and pain control in the treatment of patients who are not suitable for surgical treatment with radicular complaints due to far lateral lumbar disc hernia.

\section{CONFLICT OF INTEREST}

There is no conflict of interest. There was no grant.

\section{REFERENCES}

1. Al-Khawaja DO, Mahasneh T, Li JC. Surgical treatment of far lateral lumbar disc herniation: a safe and simple approach. J Spine Surg 2016;2(1):21-4. https://doi.org/10.21037/jss.2016.01.05

2. Erhard RE, Welch WC, Liu B, Vignovic M. Far-lateral disc herniation: case report, review of the literature, and a description of nonsurgical management. J Manipulative Physiol Ther 2004;27(2):e3. https://doi.org/10.1016/j.jmpt.2003.12.007

3. Epstein NE. Foraminal and far lateral lumbar disc herniations: surgical alternatives and outcome measures. Spinal Cord 2002;40(10):491-500. https://doi.org/10.1038/sj.sc.3101319

4. Staudt MD, Ray A, Hdeib A, Miller JP. Atypical anatomy associated with a lumbar far lateral disc herniation. Interdisciplinary Neurosurgery 2017;8:40-2. https://doi.org/10.1016/j.inat.2017.01.007

5. Park HW, Park KS, Park MS, Kim SM, Chung SY, Lee DS. The comparisons of surgical outcomes and clinical characteristics between the far lateral lumbar disc herniations and the paramedian lumbar disc herniations. Korean J Spine 2013; 10(3):155-9. https://doi.org/10.14245/kjs.2013.10.3.155

6. Baek SH, Kim ES, Kim DG, Kim HJ, Han DH. Far Lateral lumbar disc herniation. Journal of Korean Neurosurgical Society 1991;20(12):1030-9.

7. Klimov VS, Evsyukov AV, Kosimshoev MA. The modified Wiltse approach for treatment of extraforaminal disc herniation in the lumbar spine. Hir Pozvonoc 2016;13(2):62-7. In Russian. https://doi.org/10.14531/ss2016.2.62-67

8. Lee JW, Kim SH, Choi JY, et al. Transforaminal epidural steroid injection for lumbosacral radiculopathy: preganglionic versus conventional approach. Korean J Radiol 2006;7(2): 139-44. https://doi.org/10.3348/kjr.2006.7.2.139

9. Lee JW, Kim SH, Lee IS, et al. Therapeutic effect and outcome predictors of sciatica treated using transforaminal epidural steroid injection. AJR Am J Roentgenol 2006;187 (6):1427-31. https://doi.org/10.2214/ajr.05.1727

10. Fairbank J, Pynsent P. The Oswestry Disability Index. Spine (Phila Pa 1976) 2000;25:2940-53. https://doi.org/10.1097/00007632-200011150-00017

11. Filho PVM, Chueire AG. Surgical treatment of foraminal disc herniations by arthroscopic microdiscectomy. Acta Ortopédica Brasileira 2004;12(2):84-90. https://doi.org/10.1590/S1413-78522004000200003

12. Abdullah AF, Wolber PG, Warfield JR, Gunadi IK. Surgical management of extreme lateral lumbar disc herniations: review of 138 cases. Neurosurgery 1988,22:648-53. https://doi.org/10.1227/00006123-198804000-00005
13. Abdullah AF, Ditto EW, Byrd EB, Williams R. Extreme-lateral lumbar disc herniations. Clinical syndrome and special problems of diagnosis. J Neurosurg 1974;41:229-34. https://doi.org/10.3171/jns.1974.41.2.0229

14. Tessitore E, de Tribolet $N$. Far-lateral lumbar disc herniation: The microsurgical transmuscular approach. Neurosurgery 2004;54:939-42; discussion 942 . https://doi.org/10.1227/01.neu.0000115154.62636.77

15. Ohmori K, Kanamori M, Kawaguchi $Y$, Ishihara H, Kimura T. Clinical features of extraforaminal lumbar disc herniation based on the radiographic location of the dorsal root ganglion. Spine 2001;26:662-6. https://doi.org/10.1097/00007632-200103150-00022

16. Madhok R, Kanter AS. Extreme-lateral, minimally invasive, transpsoas approach for the treatment of far-lateral lumbar disc herniation: report of 2 cases. J Neurosurg Spine 2010;12:347-50. https://doi.org/10.3171/2009.10.spine08932

17. Kabil MS. The microendoscopic approach for far lateral lumbar disc herniation: a preliminary series of 33 patients. Egypt J Neurosurg 2019;34:22. https://doi.org/10.1186/s41984-019-0047-6

18. Yokosuka J, Oshima Y, Kaneko T, Takano Y, Inanami $H$, Koga $H$. Advantages and disadvantages of posterolateral approach for percutaneous endoscopic lumbar discectomy. J Spine Surg 2016;2(3):158 66. https://doi.org/10.21037/jss.2016.09.03

19. Rivera CE. Lumbar Epidural Steroid Injections. Phys Med Rehabil Clin N Am 2018;29(1):73-92. https://doi.org/10.1016/j.pmr.2017.08.007

20. Atcheson $S G$, Dymeck T. Rapid resolution of chronic sciatica with intravenous infliximab after failed epidural steroid injections. Spine 2004;29:E248-E250. https://doi.org/10.1097/01.brs.0000127192.89438.fe

21. Rust MR, Olivero WC. Far-lateral disc herniations; the result of conservative management. J Spinal Disord 1999;12:138-40.

22. Kim HJ, Park JH, Shin KM, et al. The efficacy of transforaminal epidural steroid injection by the conventional technique in far-lateral herniation of lumbar disc. Pain Physician 2012;15(5):415-20.

23. Gruenberg $M F$, Petracchi $M$, Valacco $M$, Solá $C$. Use of CT-guided periradicular injection for the treatment of foraminal and extraforaminal disc herniations. Evid Based Spine Care J 2011;2(3):19-24. https://doi.org/10.1055/s-0030-1267109

24. Weiner BK, Fraser RD. Foraminal injection for lateral lumbar disc herniation. J Bone Joint Surg Br 1997;79(5):804-7. https://doi.org/10.1302/0301-620x.79b5.7636 